\title{
Seeing Cages: Home Confinement in Early Twentieth-Century Japan
}

\section{YUMI KIM}

This article examines the visualization of "the mentally ill" (seishinbyōsha) in Japan by focusing on a psychiatric report on home confinement published in 1918. It argues that the authors of the report, psychiatrists Kure Shūzō and Kashida Gorō, mobilized a representational strategy developed mainly in a context of colonialism called the "documentary mode" to convince readers of the scientific nature of their photographs, drawings, and floor plans of home confinement. The documentary mode enabled the psychiatrists to present their viewpoint-that "the mentally ill" belonged to a distinct group deserving sympathy and medical care-as the most truthful claim, above those made by lawmakers, officials, and families. Considering the visual technologies that helped define "the mentally ill" shows how this category was in flux in the early twentieth century, subject to redefinition in the hands of those who claimed to identify, picture, and tally its members in the most truthful way.

Keywords: colonialism, confinement, documentary, home, Japan, mental illness, photography, psychiatry, visualization

$I_{\mathrm{in}}^{\mathrm{N}}$ THE summer of 1910, psychiatrist Saitō Tamao traveled from Tokyo to Miyagi village in Gunma prefecture, where he met a thirty-eight-year-old male farmer (Kure and Kashida [1918] 2000, 15). Earlier that year, the farmer had developed a strange habit of wandering aimlessly in and out of food establishments, stealing the sake and snacks of paying customers. When proprietors summoned the police, who in turn called upon members of his family, the farmer lashed out in anger. His family concluded that he had lost his mind and required care and surveillance. But there were no asylums or hospitals nearby; nor could the farmer's family have afforded such medical care anyway. So they resorted to doing what most residents of rural Japan had done since the preceding Edo period (1603-1868) to restrain mentally disturbed members prone to violence: they confined the farmer in a narrow wooden enclosure built inside the house (see figure 1).

Although domestic confinement of those considered mad was not unique to Japan, the extent of the legal obligations of care placed on families into the twentieth century was unusual. In many parts of the world, families had long sequestered mentally troubled members who posed a physical threat in makeshift enclosures. In the eighteenth-century United States and Europe, the enclosures were variously referred to as pens, stalls, apartments, and partitions (Moran 2007; Shorter 1997, 3-4), while in Korea, China, and

Yumi Kim (h.yumikim@jhu.edu) is Assistant Professor of Japanese History in the Department of History at Johns Hopkins University. 


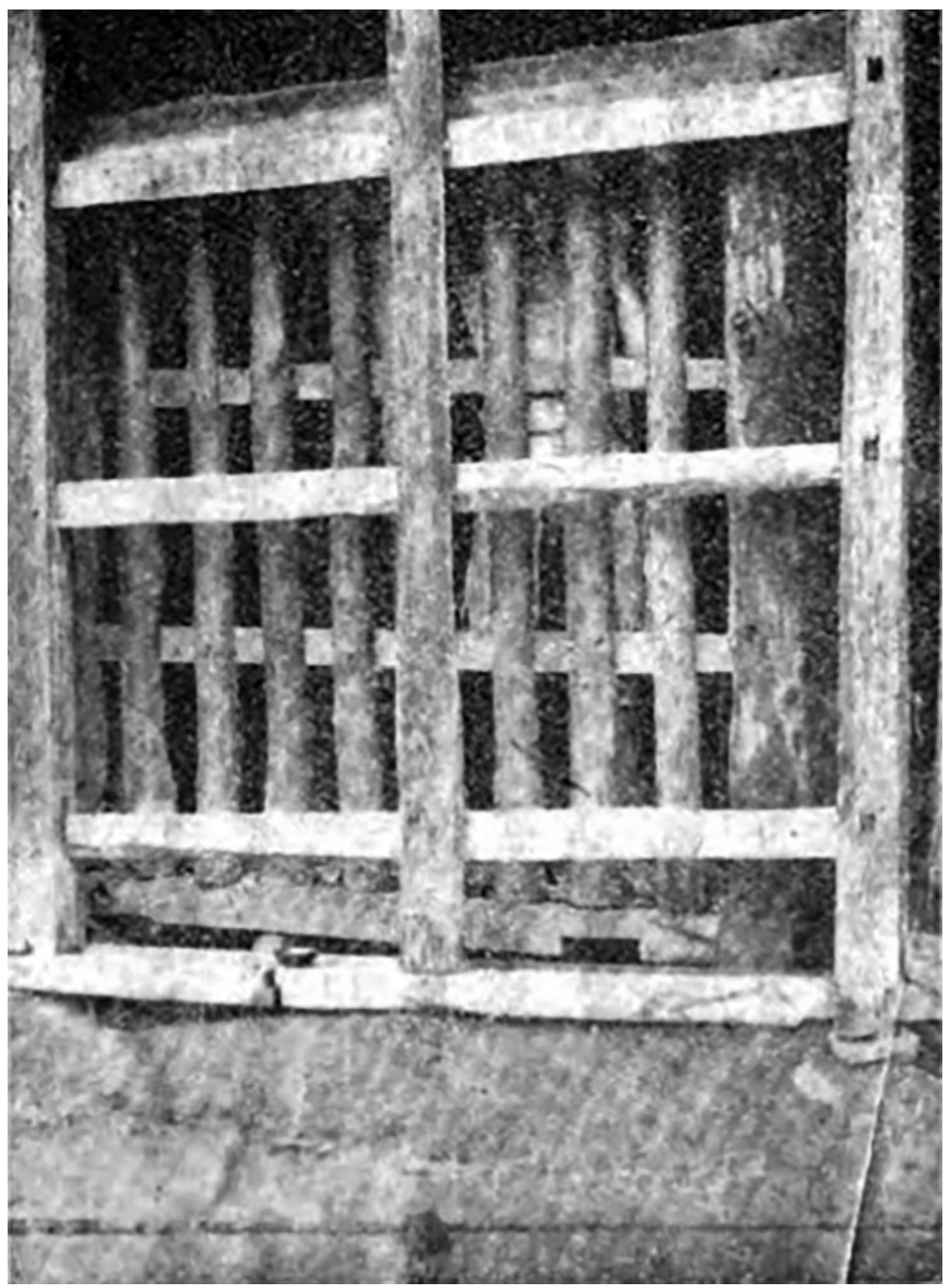

Figure 1. Example 9, Photograph 6 in Kure and Kashida (1918b).

Indonesia, families chained, handcuffed, or tied those considered mad to poles and beams inside houses (Ma 2015; Minas and Diatri 2016; Simonis 2010; Yoo 2016, 139). Yet in Japan, from the origins of home confinement in the Edo period until the practice was banned in 1950, families underwent complicated bureaucratic procedures of submitting petitions to receive permission from local officials and police to use home confinement (Hashimoto 2011; Itahara and Kuwabara 1998, 1999, 2000a, 2000b, 2001). In the wake of the Meiji Restoration of 1868, a series of new laws obligated families to support their mentally unstable members, helping to perpetuate the family-based network of caregiving established in the Edo period. From the 1870s, each of the newly created prefectures into which Japan was henceforth divided created their own laws regarding home confinement, and, in 1900, the National Diet passed the Custody Law for the Mentally Ill (Seishinbyōsha Kango Hō), which regulated the practice on a national scale for the first time. For their part, Japanese families continued to use 
home confinement because of the social pressures exerted by a longstanding "culture of domestic responsibility" (Suzuki 2003), which held families morally responsible for the criminal and socially disruptive acts of its members. The Meiji state harnessed the power of beliefs about domestic responsibility to designate "the Japanese family" as the bastion of social order, thereby avoiding the costs of a state-funded welfare system (Garon 1998, 2010).

Beginning in the late nineteenth century, the first Japanese psychiatrists challenged the primacy of the family. Armed with new ideas about madness derived mainly from German psychiatry, the psychiatrists claimed that doctors based in mental hospitalsnot families in their homes - ought to be the main caregivers. ${ }^{1}$ The psychiatrists diagnosed the confined with seishinbyō, which literally meant "sickness of spirit" and can be rendered in English as "mental illness." This new term for madness contained the idea that the mind was susceptible to biological diseases triggered by physical lesions in the brain, inherited psychological traits, or both. Japanese had long attributed madness to spirit possession and blockages of ki energy (Hiruta 1985; Hyōdō 2008). The psychiatrists hoped to replace supernatural and immaterial explanations with the medical understanding of madness as disease. Unlike state officials who targeted the mentally disturbed as a potentially dangerous group of social deviants or families that feared the potential violence caused by a member's strange behavior, psychiatrists argued that "the mentally ill" ought to be regarded as sick patients deserving medical care and sympathy. The psychiatrists demanded that the government ban home confinement and build more public psychiatric hospitals. ${ }^{2}$

To convince officials of the need for institutional reform, psychiatrists conducted ethnographic surveys that documented what they perceived as the harsh realities of home confinement. From 1910 to 1916, Kure Shūzō, the head of the Department of Psychiatry at Tokyo Imperial University's medical school, led a team of twelve psychiatrists in collecting information, statistics, floor plans, and photographs of home confinement in fifteen prefectures, most clustered near Tokyo, but some as far as Hiroshima in the southwest and Aomori in the northeast. In 1918, Kure and medical student Kashida Gorō selected over 100 among the 364 observed cases and published an official report in the esteemed Tōkyō Igakukai Zasshi (Tokyo Journal of Medical Science) under the title "Seishinbyōsha Shitaku Kanchi no Jikkyō Oyobi Sono Tōkeiteki Kansatsu” (Actual Conditions of Home Confinement and Statistical Observations of the Mentally Ill; Kure and Kashida 1918a). ${ }^{3}$ In the same year, the Bureau of Hygiene in the Home Ministry published the report as a book and distributed it to other government agencies (Kure and Kashida 1918b). The report was aimed at doctors, researchers, bureaucrats, politicians, police, and legislators who were in positions to change the laws governing home confinement.

\footnotetext{
${ }^{1}$ Although many psychiatrists condemned the practice of home confinement, some promoted other kinds of "family care," especially the placement of those considered mentally ill in the homes of families other than their own (see Burns 2017).

${ }^{2}$ The first public mental asylum was built in Kyoto. The Tōkyō Tenkyōin (Tokyo Public Asylum) was established in 1875. Some of the earliest private asylums were built in Tokyo around this time. For more on mental hospitals, see Okada Yasuo (1981), Omata (2000), and Kanekawa (2009, 2012). ${ }^{3}$ Most of the original reports of the team of psychiatrists are no longer available, with the exception of Saitō Tamao's surveys conducted in Gunma (Saitō [1910] 2010-11) and Yamanashi Prefectures (Saitō [1911] 2010-11).
} 
Kure's report contributed to the creation of the modern category of "the mentally ill" (seishinbyōsha) in Japan by visually and numerically distinguishing certain individuals as belonging to a distinct social group deserving sympathy and medical care. The report mobilized what I call a "documentary mode" to convince readers of the truthfulness of the psychiatrists' claims. The documentary mode was a form of representation developing at the turn of the twentieth century in Japan and elsewhere that drew from an earlier statistical tradition of social research (Kawai 1989-94), but increasingly engaged such visual technologies as photography and cartography to lend an aura of scientific objectivity to the objects under observation, especially within a context of colonialism. From the far reaches of the British Empire to the American West, colonizers, surveyors, and scientists mobilized photography as a tool of surveillance, control, and knowledge-making (Edwards 1992; Lydon 2005; J. Ryan 1997; S. Ryan 1996; Snyder 2002). As Jane Lydon $(2005,3)$ has described, "[photography's] seeming veracity drew it into the service of state and empire, apparently able to classify human variation and behavior factually, impartially, and completely."

In Japan, too, new visual technologies were linked intimately with colonialism (Blaxell 2009; Kim 2016; Low 2003). In the settlement of Hokkaido, photographic documentation of the construction of roads and government buildings in Sapporo in the early 1870s helped articulate a new vision of the nation as "progressive" and "modern" (Kim 2015, 351). In Taiwan, the camera captured images before and after colonization in 1895, with photographer Matsuzaki Shinji accompanying the initial Taiwan expedition of 1874 (Kinoshita 2003) and anthropologists Torii Ryūzō and Mori Ushinosuke producing well-known anthropometric photographs of indigenous peoples in the 1890s and 1900s (Barclay 2016; Wong 2009). Early developments in Japanese film, especially the "real conditions film" (jikkyō eiga) or "actuality film" (jissha eiga), later to be called "documentary film" (dokyumentarii eiga), speak to a growing interest in both factual and visual representation of the colonies and beyond. Kure's report, too, included the word "jikkyō" (actual conditions), similar to titles of films like Taiwan Jikkyō Shōkai (An Introduction to Actual Conditions in Taiwan, 1907) and Kankoku Isshu (Around Korea, 1908; Nornes 2003, 12). Presented in the documentary mode, photographic and cinematic images appeared as passive and precise imprints of truth, achieving status as evidence of actual conditions of life.

The images of home confinement in Kure's 1918 report suggest that the visualization of people and places regarded as socially marginal or geographically peripheral within Japan both drew on and helped develop the documentary mode. Whether the rural countryside or urban slums, juvenile delinquents or the so-called mentally ill, the "actual conditions" of such localities and lives came under the scrutiny of social scientists, doctors, ethnographers, surveyors, government officials, and reformers in the early twentieth century (Ambaras 2005; Kawai 1989-94; Silverberg 2006). In writing his report, Kure stressed the importance of "seeing" such actual conditions. The photographs of the confined and their enclosures rendered visible a practice that usually remained hidden from public view. Other than affected families and local police, few bore witness to actual cases of home confinement. "The numerous photographs and figures included in this book as illustrative examples," Kure wrote, "truthfully relate the horrible sight of confinement rooms." He was certain of "the unbearable heartache that the reader will feel [at the sight of] the extremely cruel treatment [of the mentally ill] outside hospitals." "Seeing" 
the misery would arouse readers' sympathies sufficiently to initiate the reform measure Kure proposed: ban home confinement and build public psychiatric hospitals. "We ask," Kure wrote, "for your sympathy $(d \bar{o} j \bar{o})$ for the most unfortunate among the sick, and hope that you will do all you can as soon as possible to [establish] a system [of care] and improve [current] facilities" (Kure and Kashida [1918] 2000, 3-4). ${ }^{4}$

Kure deployed the documentary mode to arouse sympathy for the confined and their families. As a representational strategy, the documentary mode worked by concealing the subjective mechanisms by which its apparent objectivity was constructed. Any desired sympathetic response to "horrible" conditions of confinement stemmed not from the photographic medium itself, but through the selection, cropping, framing, arrangement, and deletion of images. The documentary mode was premised on maintaining a critical distance between observer and observed, but in fact invited viewers into deeper and more intimate engagements with the text and images of Kure's report. While appearing as detached and objective visual representations of home confinement, the images drew readers into the world of everyday experiences of families that included the labor of caregiving, movement across spatial boundaries, and sensory contact. Engagement was likely to elicit sympathy. The documentary mode helped such emotions as sympathy seem like natural and inevitable ways of responding to "the mentally ill," fulfilling Kure and fellow psychiatrists' hope to bring this group within the purview of psychiatric care.

Considering the contributions of Japanese psychiatrists to the creation of the documentary mode places them within a broader Meiji and global context of colonialist impulses and civilizing missions. It resists isolating the history of Japanese psychiatry as its own subfield about the growth of academic psychiatry, and instead highlights the ways in which changing notions of madness were embedded within the forces of nation- and empire-building at the turn of the twentieth century. ${ }^{5}$ Yet Japanese psychiatrists were not appendages of the new Meiji state. Nor was home confinement simply another means by which agents of the newly formed modern state, including psychiatrists, intervened in the everyday lives of its citizen-subjects, as some otherwise excellent accounts have suggested (Hyōdō 2008). Psychiatric research was financially supported by the state, but as in the case of Kure's report, such research was often an important, if not the only, source of criticism of government policy regarding the mentally disturbed. Attention to such criticism helps disaggregate the state into its constituent and often conflicting parts. Finally, considering the representational strategies and visual technologies involved in shaping a category of people undermines one of the biggest assumptions in the current literature on mental illness in early twentieth-century Japan: that "the mentally ill" was a stable and self-evident category since its introduction in the 1870s. Through

\footnotetext{
${ }^{4}$ Yamane Masatsugu, a member of the House of Representatives, invoked psychiatrist Saitō Tamao's 1910 survey of home confinement in Gunma prefecture, which Kure included in his report of 1918, during a committee meeting concerning government facilities for the mentally ill on March 20, 1911. He repeatedly urged the committee members to look at Saitōss photographs, exclaiming that the images proved the need for reform (Utsunomiya 2009).

${ }^{5}$ One notable exception is Kazamatsuri's (2012) study of the transfer of psychiatric knowledge from Tokyo Imperial University to colonial Korea's Keijo Imperial University in the early twentieth century. Recent works by Watarai (2003), Burns (2012), and Satō (2013) analyze the roles of social experience and cultural beliefs in the formation of notions of mental illness in the contexts of nationalism and Western imperialism.
} 
their ethnographic-scientific reports, Japanese psychiatrists countered legal, police, and familial understandings of those considered mad, showing how "the mentally ill" was a category in flux, subject to redefinition and reshaping in the hands of those who claimed to identify, picture, and tally its members in the most truthful way.

\section{From Parlor Prison to Home Confinement in the Edo Period}

Before the late nineteenth century, the "mentally ill" did not constitute a distinct social group in Japan. Individuals were certainly identified as "mad" or "deranged" (kichigai), but neither families, local officials, nor doctors viewed them as belonging to a fixed category of people. Families were often the first to diagnose whether a member had lost his or her mind, calling in such local healers as village doctors and exorcists to try to relieve the cause of madness, whether spirit possession, disordered ki energy, or psychological troubles (Hiruta 1985; Hyōdō 2008). To manage long-term cases of madness, families chose one among three options: placement in a local prison $(j u r \bar{o})$, in a detention center (tame), or at home (Itahara and Kuwabara 1998, 1999, 2000a, 2000b, 2001). All three options were associated with disciplinary action, but only home confinement was carried out in a private setting.

Home confinement most likely originated in the sixteenth or seventeenth century as a form of discipline and punishment directed at disobedient, but not necessarily deranged, family members. ${ }^{6}$ One of the most common targets of confinement was the "profligate son" (hōto musuko), whose father would throw him into a zashikirō, or "parlor prison," a formal sitting room turned into a prison-like cell, either by replacing the sliding doors with wooden bars or by constructing a wooden cage inside the room. Fathers confined sons in hopes that restricting their movement would compel them to reflect on past indiscretions and resolve to mend their ways. The low-ranking samurai Katsu Kokichi (1802-50), forced to return home after having run away, found that a cage (ori) the size of three tatami mats had been set up in the middle of the sitting room (zashiki). As Katsu relates in his autobiography of 1843, he lived inside the cage for three years, following his father's instruction to "think long and hard about [his] life" (Katsu [1843] 1969, 60). Sons who served time in parlor prisons were usually, like Katsu, from the samurai class or wealthy commoner families who could afford to hire carpenters to construct cages and delegate the task of feeding and caring for the son to a servant in the household. ${ }^{7}$ Spaces of domestic confinement came to be associated with the pacification and moral reform of privileged but unruly young men.

Drawing on the custom of confining sons at home, families dealing with the disruptive behavior of a member who seemed to have lost his or her mind chose to confine at

\footnotetext{
${ }^{6}$ There is some fragmentary evidence of home confinement before the Edo period in such sources as Kōyo Gunkan (1616) and Nippo Jisho (1603), the Japanese-Portuguese dictionary compiled by Jesuits. In the Edo period, the practice was variously referred to as sashiko 指籠 (or 差籠 or 指子) and uchiori 内折 (Hiruta 1985, 60).

${ }^{7}$ Edo literature and poetry are laced with references to parlor prisons. One well-known example can be found in "Kibitsu no Kama," a story from Ueda Akinari’s Ugetsu Monogatari (1776) (Nakamura Masaichi 2010). See also senry $\bar{u}$ poetry in Okada Hajime (1976-78). For a literary example from the twentieth century, see Shimazaki ([1929] 1987).
} 
home. The earliest known record of home confinement for those considered mad dates to the mid-1700s. Historians Itahara Kazuko and Kuwabara Haruo argue that Edo households chose home confinement only for members with senior status in the family, namely parents, grandparents, uncles, and heirs. ${ }^{8}$ In a society abiding by Confucian notions of hierarchy, it was difficult to subject family elders to treatment that resembled disciplinary action in a public space such as the local prison or detention center. Persons of elevated status therefore tended to be confined at home, and permission for their confinement entailed a complicated bureaucratic procedure that ensured that household members and village elders had collectively agreed to confinement.

The few extant records of early modern laws and provisions concerning the insane indicate that at least five different groups of people were involved in the process of legally confining a mentally disturbed person: the family, relatives, the five-household group, local officials, and the city or district magistrate. At times a physician's diagnosis was also required. Guidelines written in 1814 for Edo city magistrates entitled "Inspections of Caging on Account of Insanity" state that the first step in the permissions procedure was taken by the extended family when they collectively declared that a member was mad: "Parents and siblings, as well as relatives, should decide whether [this is a case of] insanity, and obtain endorsement from a [city] official" (Hiruta 1985; Itahara and Kuwabara 1999, 95). In order to obtain the endorsement, families were required first to submit to a local official a request signed by the family and relatives and representatives of the five-household group. The official visited the family to perform the "inspection" to verify that a member was indeed insane. Pending inspection, the official forwarded the request, along with a sketch of the layout of the residence and projected location of the cage, to the town or district magistrate. The magistrate often sent out an official to inspect the residence and sick person, only then granting permission to confine. The sequence of persons consulted, starting from the extended family and five-family group to the local officials and magistrate, reflects the hierarchy, in reverse order, of the institutions that governed the lives of commoners in the Edo period.

Officials oversaw the domestic confinement of the insane because they were concerned about preventing household strife that might produce grievances leading to the dissolution of a household. Dissolution meant one fewer taxable units and one more source of social and economic instability. Families, too, worried about strife that might prevent smooth succession. A 1793 request for permission submitted to the city magistrate in Edo to confine a pawnshop owner named Tenjun, a household head in the district of Kanda, illustrates one family's concerns for domestic stability. The petitioner, Tenjun's mother, explained that Tenjun's sickness had made him violent and that he was disturbing the daily operations of the business. He was not only throwing household items, but also beating his wife and employee, and so the family was requesting that he be confined in a cage. Tenjun's mother assured officials that succession would be smooth: "in regards to the family estate, we have the name of my grandson written as the successor" (Itahara and Kuwabara 1998, 42-47). Such concerns about succession, domestic violence, and everyday life shaped both official and familial responses to and understandings of madness in the Edo period.

${ }^{8}$ Itahara and Kuwabara (1998, 1999, 2000a, 2000b, 2001) expand an argument first presented by Yamazaki (1932) that the fear of family feuds motivated the decisions of households regarding private confinement. 
In the succeeding era, familial involvement would remain constant, but official interest would intensify, as national and local government agents like the police became increasingly involved in managing the movements of those considered mad.

\section{Meiji Police and Lawmakers Create “the Mentally Ill”}

New Meiji officials such as the police were among the first to shape "the mentally ill" (seishinbyosha) as a legal and social category. With the Meiji Restoration of 1868 that toppled the old order and ushered in massive social dislocations and cultural change, families were compelled to adapt to new institutions and laws concerning madness. In the place of neighborhood heads and city magistrates, newly created prefectural police were charged with monitoring the mentally disturbed. The police were one of many administrative institutions created by the leadership of the newly centralized state as part of the mission to strengthen and reform the nation. Acting as the guardians of the public peace in unprecedented ways, the Metropolitan Police Office of Tokyo, established in 1874 in the Home Ministry, began managing many aspects of daily life in the new capital city. Although technically responsible for security maintenance only in Tokyo, the Metropolitan Police Office quickly became the model for police systems in other prefectures. The nearly 6,000 newly recruited patrolmen were assigned a broad range of duties, from supervising commercial activities and conducting population counts to preserving public morals and compiling information on residents of each neighborhood. No other security institution in Japan had ever been as large or as far-reaching. The police carried out paternalistic measures of preventive policing, recording and punishing ordinary people's customs and habits for the sake of stifling social unrest (Umemori 2002).

As caretakers of the people, the Metropolitan Police Office took over the administration of the private home confinement of those considered mad in the 1870s. Its foremost concern was maintenance of the public peace during a time of regime change and therefore the ability to distinguish between various forms of social disturbance, whether mental illness or crime. As early as 1874, the Police Office issued an ordinance that ordered families to watch strictly over any mentally troubled members, and in May 1878, it announced the first major directive aimed at "caring for insane persons (fütennin) and controlling wayward children":

Those who have no choice but to enchain at home in order to care for an insane person (fütennin) or discipline a wayward child must first send to the ward chief a detailed description of the reason for confinement signed by two family members (and in the case of a mentally ill person a doctor's diagnosis form as well), in accordance with the procedure for placing in a cage [those who require reform], as outlined in the police ordinance of March 10, 1876, and then receive permission from the police office in the appropriate jurisdiction. (Keishi Ruiju Kisoku 1879, 432)

\footnotetext{
${ }^{9}$ This was Ordinance 172. Historians have suggested that the intensification of police laws was a result of the Soma Incident of 1884, a case of wrongful confinement of a former daimyo (see Burns 2000, 42; Hashimoto 2011; Utsunomiya 2009).
} 
As the 1878 directive indicated, "wayward children" who had been subject solely to parental authority in the Edo period now came under the jurisdiction of the police. The language used to describe the status of the mad and their confinement also shifted. Replacing the term "ranshinsha," used commonly in the Edo period, was "fütennin." The latter had first appeared in an official document in the Shinritsu Kōryō of 1870, the Meiji penal code in place before what became known as the Old Criminal Code was instituted in 1882 (Kanekawa 2012). If ranshinsha was a general word, the equivalent perhaps of "madman" or "madwoman," then fütennin was a specialized term with medico-legal resonances, along the lines of "mental patient" or "insane person."

Prefectures quickly followed suit, issuing their own ordinances governing "the mentally ill." Although the ordinances varied among prefectures, many specified in detail the material requirements and administrative procedures of home confinement. Chiba prefecture issued "Regulations for the Management of Insane Persons" in 1889, a thirteen-article ordinance that declared it essential that all "insane persons," regardless of whether they were confined or not, register with the police and be accompanied in all public places by a designated legal guardian (Hashimoto 2011, 31). Hygienic standards were imposed, directing how much sunlight and air circulation the "enchainment room" ought to receive. The use of forceful constraints, whether iron chains or ropes, was prohibited, as was the placement of flammable materials near the room. Families were subject to fines if they did not follow the terms of the ordinance. Although the content of the various prefectural ordinances was more or less the same, the language used to describe the mentally unsound person or the practice of home confinement, as well as the procedure of attaining permission for either home or institutional confinement, was not yet uniform. Only with the establishment of a national law concerning "the mentally ill" was uniformity in at least language and law achieved.

In 1900, the Imperial Diet passed the first piece of national legislation concerning the management of madness, known as the Custody Law for the Mentally Ill (Seishinbyōsha Kango Hō). The Custody Law shifted the locus of decision-making power for cases of confinement from the family-household-village nexus of the Edo period to the newly created figure of the legal custodian. This law required that each mentally unsound person be assigned a custodian, usually the household head, who assumed all legal and financial responsibility for the patient. Whereas in the Edo period any member of the patient's family could petition local authorities to confine or release a person, the Custody Law allowed only the legal custodian to authorize the confinement of the afflicted person, whether at home in a cage-like enclosure or in one of the newly built public or private psychiatric hospitals. In the case that a competent custodian could not be found, the city or prefectural administrative head would serve as the acting custodian. The Custody Law also explained the fines and punishment for wrongful confinement, that is, confinement without the approval of local authorities or with falsified documents.

The Custody Law and the new emphasis on the figure of the legal custodian were not created by the police, families, or psychiatrists, but by legal scholars and Diet members seeking to establish a modern legal system in Japan. Ume Kenjirō, one of the three key jurists who revised the Civil Code, initiated calls for the creation of a supplementary law concerning the management (torishimari) of those considered mentally ill at the administrative level as well as the protection of not only their property, already addressed by the 
Civil Code, but also their "body and rights" (Utsunomiya 2010). The resulting Custody Law, much like the Civil Code, subsumed such rights under the concept of familial custodianship. In what amounted to a reinforcement of the idea that the household was the primary unit of society, the mentally disturbed were placed in the custody of their families, the assumption being that the family was the natural locus of care and surveillance. The Custody Law reinforced an ideology enshrined in the Civil Code, namely the unquestionable authority of the patriarch and the social function of the family as guardian of social order.

Yet the passage of a national custody law rooted in Meiji ideological and legal discourses of the family did not significantly change actual practices of confinement. The procedure of attaining permission to construct cage-like rooms remained more or less the same across prefectures, despite the replacement of village officials with the police as the main public agents in charge. For families living with home confinement, the regulations detailed in the Custody Law were bureaucratic matters that required attention, but they had a minimal effect on everyday life, where it did not always matter whether the legal custodian was the patriarch of the family since the labor and emotions of care were shared among members both inside and outside the family. Reasons for confinement also remained more or less the same across the Edo-Meiji divide. ${ }^{10}$ As in the Edo period, families confined at home, no matter the financial and emotional burdens, because it was a practical way of controlling various forms of violence, including throwing items, hitting passers-by, stealing from neighbors, stabbing relatives, and starting fires. Based on such experiences of violence and disruption, families formed social understandings of madness and treatment that new Meiji psychiatrists would aim to counter.

\section{Enter Psychiatrists}

Early Japanese psychiatrists like Kure Shūzō aimed to change legal and social understandings of "the mentally ill" as irremediable members of society by persuading officials that such people deserved, above all, sympathy and medical care. Whereas legal scholars were concerned with the standardization of legal codes concerning madness and families were preoccupied with managing unpredictable and strange behaviors, psychiatrists viewed "the mentally ill" as requiring what Kure called "practical," or medical, treatment. Their assertion of authority over the treatment of "the mentally ill" stemmed, in part, from their attempt to lay claims to new professional territory in which psychiatristsnot policemen or families — would perform the work of diagnosis and management. ${ }^{11}$

Psychiatry as a medical science was first established in Japan as part of government efforts to improve the health of its citizens through the construction of a modern medical

\footnotetext{
${ }^{10}$ Some differences existed. For instance, in the Meiji period, individuals seen as mad were often confined for acts of lèse majesté against the emperor or for breaking into local government offices. See the statistical compilation of reasons for confinement in the appendices of Kure and Kashida (1918a).

${ }^{11}$ Kure aimed to prevent police from acting as doctors. Under the Custody Law of 1900, the police collected information on the patient's personality, behavior, medical history, cause of illness, assets, confinement method, and more.
} 
and public health system. Beginning in the early 1870s, central and local government officials began to build medical schools and institute a system of state licensing, legally elevating Western medicine over traditional forms of medical practice. They hired German physicians to work in universities and hospitals in cities like Kyoto, Osaka, Nagoya, and Tokyo. In 1879, Erwin Baelz became the first physician hired to give lectures on psychiatry in the Department of Medicine at what would later become Tokyo Imperial University. The government also encouraged medical students to study psychiatry in Germany and Austria. In 1883, the Ministry of Education dispatched Sakaki Hajime, a recent graduate of the new Department of Medicine, to study psychiatry in Berlin and tour state-supported asylums in Germany and Austria. Upon returning in 1887, Sakaki was named the first chair in psychiatric medicine at Tokyo University Medical School and the founding director of the Tokyo Public Asylum. Sakaki’s successor was Kure Shūzō, the lead author of the 1918 report on home confinement.

Kure's report belonged to a broader, global development at the turn of the twentieth century: the visual and numerical documentation of people and places considered socially and geographically peripheral or colonial through such new technologies of mass representation as photography and film. Kure and his fellow psychiatrists focused on the rural Japanese countryside, the site of most cases of home confinement. Views of the countryside as "backwards" and "uncivilized" had been commonplace since the early Meiji years. New urban professionals such as psychiatrists and other Western-trained doctors viewed the countryside as a repository of harmful superstitions and customs. Tokyo doctor Takahashi Shinkichi claimed that beliefs about animal spirit possession as the cause of madness, for instance, occurred in "poor and backward places where there are many ignorant people," and more rarely in urban areas like Tokyo "where human knowledge had advanced" (Burns 2012, 95). By dispatching Tokyo-based psychiatrists and medical students to rural areas where home confinement was most prevalent, Kure participated in the broader Meiji project of "civilizing" the countryside on terms created by new urban professionals.

Yet the civilizing mission of the psychiatrists involved inciting other urban professionals and state bureaucrats to action, rather than blaming rural families for the cruelties of home confinement. ${ }^{12}$ Objective and detached vision that would generate feelings of sympathy was crucial to this project. To convey a sense of objectivity, Kure, with the help of medical student and co-author Kashida Gorō, created the kind of visual consistency and uniformity found in medical and anthropological reports of the time. In their content, the photographs of home confinement varied widely. Some captured the hunched figures of the confined (see figure 2); others highlighted structural features such as the doors, hinges, and padlocks of rooms. Still others resembled portraits with the faces and shoulders of the confined at the center of the images.

To suggest that such diverse images represented the same thing, namely the "actual conditions" of home confinement, Kure and Kashida cropped all the photographs to the same size. Consider Photograph 32, in which a confined man peers out from behind the bars of his wooden cage (see figure 3 ). The viewer's eye is led to focus immediately

\footnotetext{
${ }^{12}$ Alongside cases of home confinement, Kure's report included examples of religious treatments at temples, hot springs, and other sites (see Harding, Iwata, and Yoshinaga 2015; Hashimoto 2010; Nakamura Ōsamu 2013).
} 


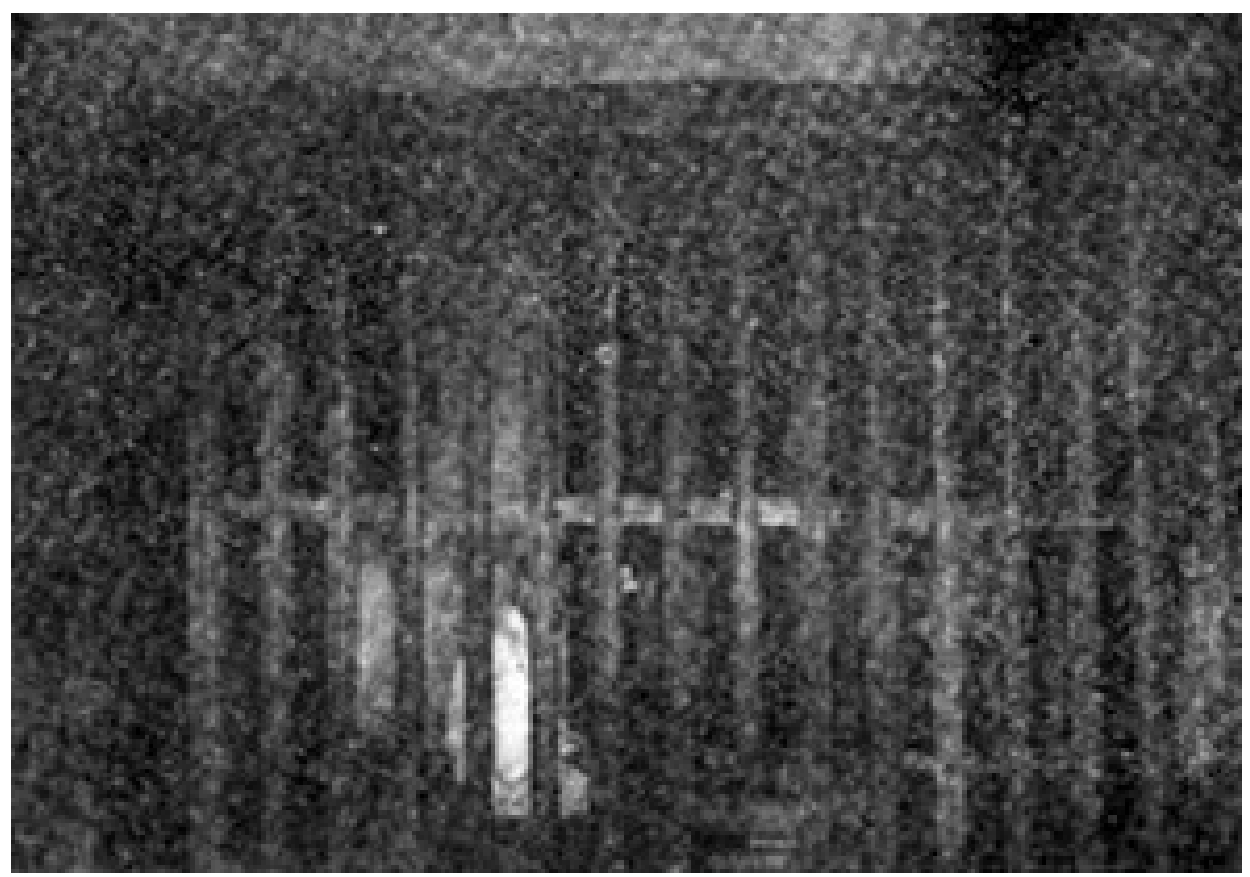

Figure 2. Example 7, Photograph 4 in Kure and Kashida (1918b).

on the man's face at the center of the image, framed by four hefty vertical logs and two thin horizontal rods. His gaze feels startlingly direct in part due to its position in the center of the image. In contrast, in an unpublished version of the photograph, the one from which Photograph 32 was likely created, the viewer's attention is drawn not to the man's face, which is no longer in the center, but to the point at which the wooden bars on two sides of the cage meet at the bottom-right corner (see figure 4). Kure, Kashida, or another assistant cropped Photograph 32 so that it was the same size as the other photographs in the report and eliminated the tilt in the unpublished photograph that lent it a casual, unscientific air. Both versions, along with the report's many other images of the confined behind bars, reinforce a sense of the distance between viewer and viewed. The confined man's fingers lightly grasp the wooden post, his head pressed between parallel posts, making viewers aware of the wooden bars acting as a barrier. The cage-like spaces compelled one observing psychiatrist to describe the sight of the confined as "something from a zoo" (Kure and Kashida [1918] 2000, 20). Indeed, the bars of the wooden cages are evocative of the thick metal rods used to enclose animals at the newly established Meiji imperial zoo, many of which would soon be replaced by glass and thinner steel bars to convey an "illusion of immediacy" and access to the creatures on display (Miller 2013). Here in the images of the wooden cages, the extent of such access remains ambiguous.

Other images in the report, including floor plans and hand-drawn illustrations, were standardized for the sake of uniformity and legibility. A comparison between a case that appeared in a report on home confinement published by psychiatrist Saitō Tamao in 1910 (see figure 5) and an adaptation of the same report in Kure's publication of 1918 (see 


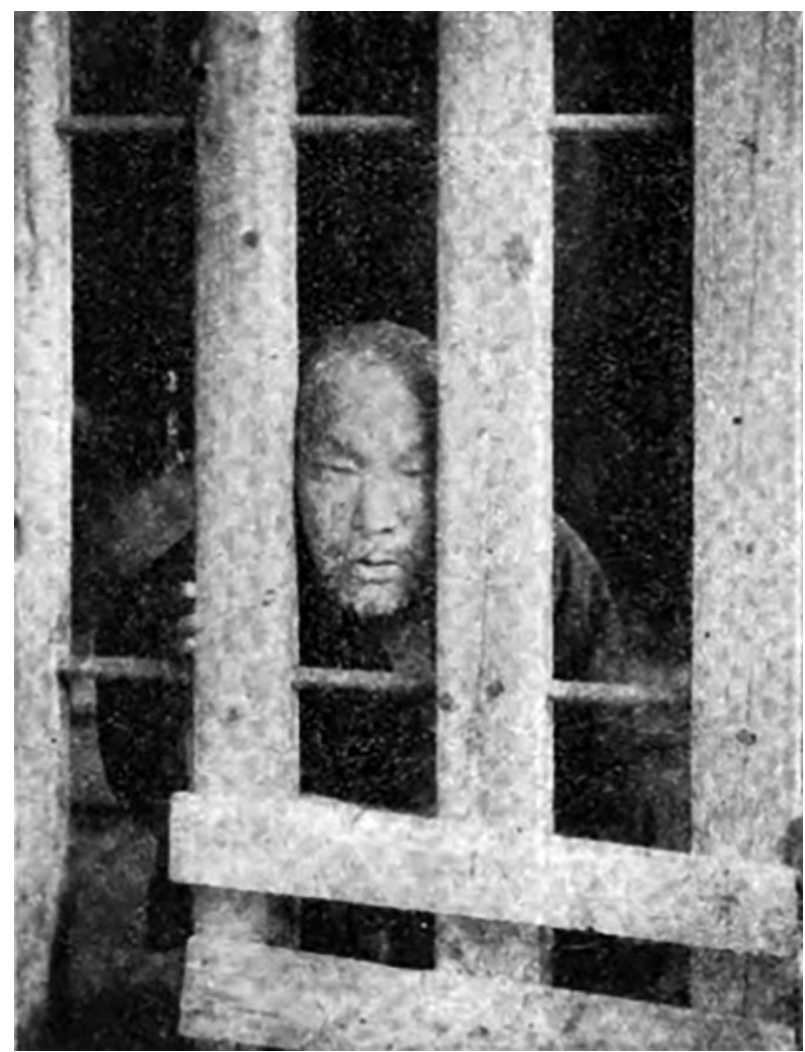

Figure 3. Example 53, Photograph 32 in Kure and Kashida (1918b).

figure 6) reveals that Kure and Kashida redrew the floor plans so that the handwriting, thickness of lines, and symbols were uniform throughout the report (Saitō [1910] 2010-11). Like the photographs, the floor plans varied widely in content, depending on the individual observing psychiatrist or the police records available to him. Some included only basic information about the location of the confinement room inside the house, while others featured precise locations of kitchens, bathrooms, doors, main rooms, and storage areas as well as landmarks such as fields, streams, and gardens, showing the layout of the house and its surroundings. By redrawing the floor plans, such marks of individuality as Saitōs handwriting and his idiosyncratic drawings were erased. $^{13}$

Yet the hand at times provided more legibility than cameras. Some photographs collected by the team of psychiatrists were converted to hand-drawn illustrations. Saitōs report of 1910 included a photograph of the exterior of the confinement room, which Kure modified into a drawing for his report of 1918. The drawings were intended to function the same way as the photographs, as suggested by the fact that the drawings, too,

\footnotetext{
${ }^{13}$ Many observing psychiatrists copied floor plans and information from police logbooks known as the "Record Book of the Mentally Ill in Confinement." Local police often assisted the psychiatrists (see Ujiie 1942).
} 


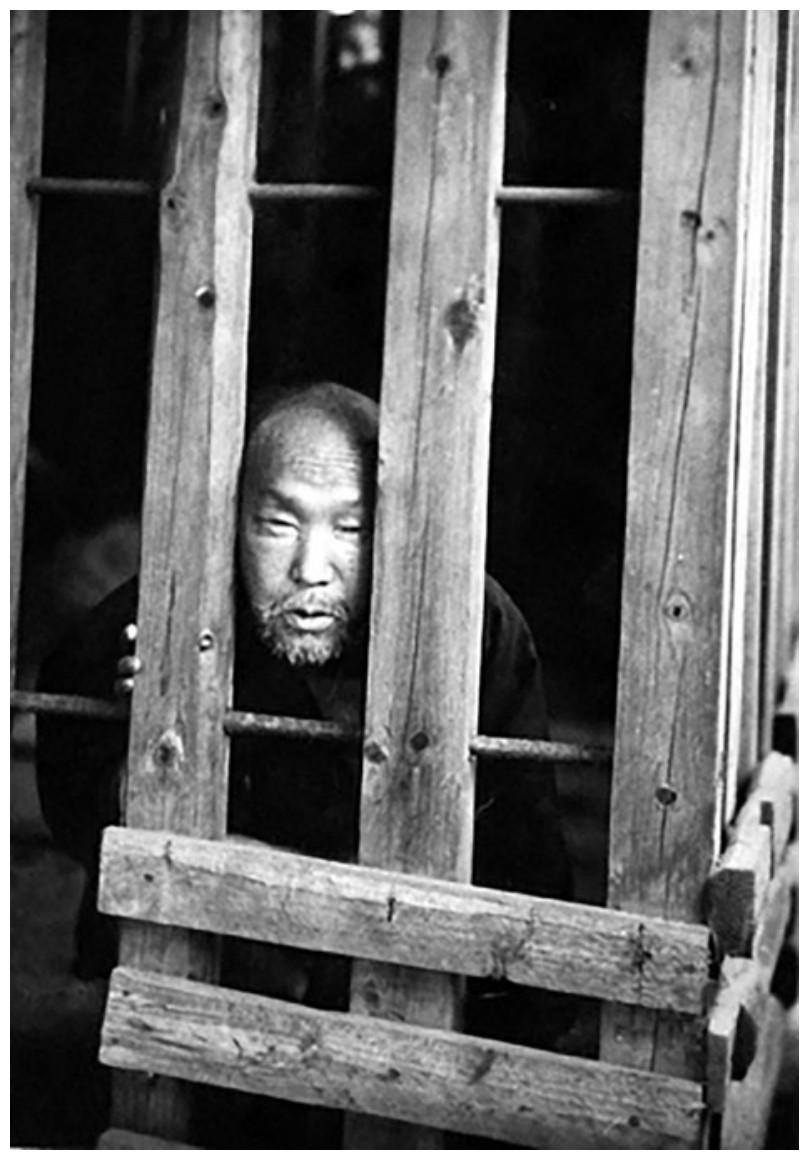

Figure 4. Courtesy of the Komine Research Institute for the History of Psychiatry, Keio University, Tokyo.

were labeled in their captions as "photographs" (shashin, literally "reflection of the real"). Although neither Kure nor Kashida mention the reason for converting photographs into drawings, it is likely that it made for increased legibility. The drawing of Saitō's case, for instance, slices away the foreground in the photograph so that the focal point becomes the protruding bay window of the house, not the bumpy ground leading up to the footbridge. The drawing contains fewer visual distractions than the photograph with its shadows that make certain parts indiscernible. With little effort, the viewer can see the clear lines of a footbridge, dam, bay window, and beams. Eliminating the blurriness and shadows of the roof and eaves, the drawing sharpens the original photographic image. As a result, the house appears tidier. Window coverings are not bent out of shape, as in the photograph, and the wooden barrier of the bay window is not worn-out. In a pastoral style, the drawing romanticizes the countryside home with gentle shading and soft light.

Although visual uniformity created the impression of a detached and objective viewing experience, the composition and arrangement of images and text in Kure's report encouraged deep engagement. Increased legibility allowed viewers of the 


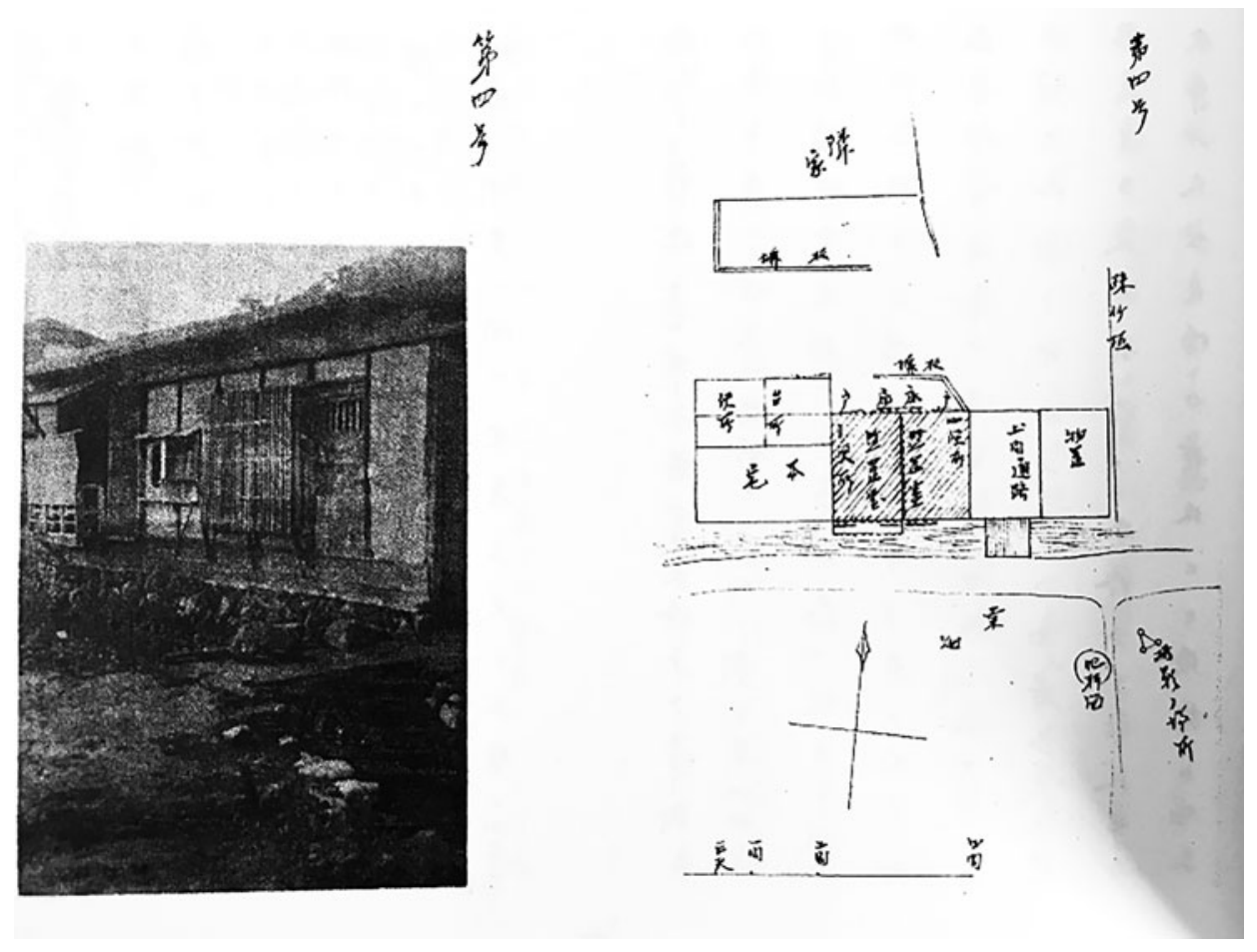

Figure 5. Example 4 in Saitō Tamao, "Gunma-Ken Kanka Seishinbyōsha Shitaku Kanchi Jyōkyō Shisatsu Hōkoku" (1910) from the Komine Research Institute for the History of Psychiatry, Keio University, Tokyo. Reprinted in Saitō ([1910] 2010-11).

report to look more closely, as if each case presented a puzzle in which the viewer fit together text, photograph, drawing, and floor plan to be able to "see" home confinement. In the case of a forty-two-year-old woman, a former instructor at the Prefectural Technical School who was confined after she hit her mother and broke household items, the photograph of her confinement room appeared alongside a detailed floor plan of the residence and explanatory text, the former helping to visualize descriptions in the latter two (Kure and Kashida [1918] 2000, 44-45; see figure 7). The floor plan indicates the spot from which the photograph was taken with a triangle symbol, allowing the viewer to place himself or herself in the position of the on-site observer. The eyes travel back and forth from the photograph, floor plan, and text. The floor plan shows that the room was located inside a building attached to the main house on the east side. The text describes the wooden floor of the confinement room as having been covered with two rotten tatami mats stained with urine. The photograph shows the wooden bars of the enclosure, its measurements recorded in detail in the text, as well as the light streaming through windows in the back of the cage. The various images in this case, combined with textual description, help spatialize the rooms and contextualize them within the broader space of the house.

The arrangement of visual and textual materials highlighted the ways in which the confinement rooms were embedded in both domestic and public spaces. Three distinct but nested spaces come into view: the neighborhood or village, the home, and the 
例二十7i第及例一十五第

(踋一十: 第) 谈第

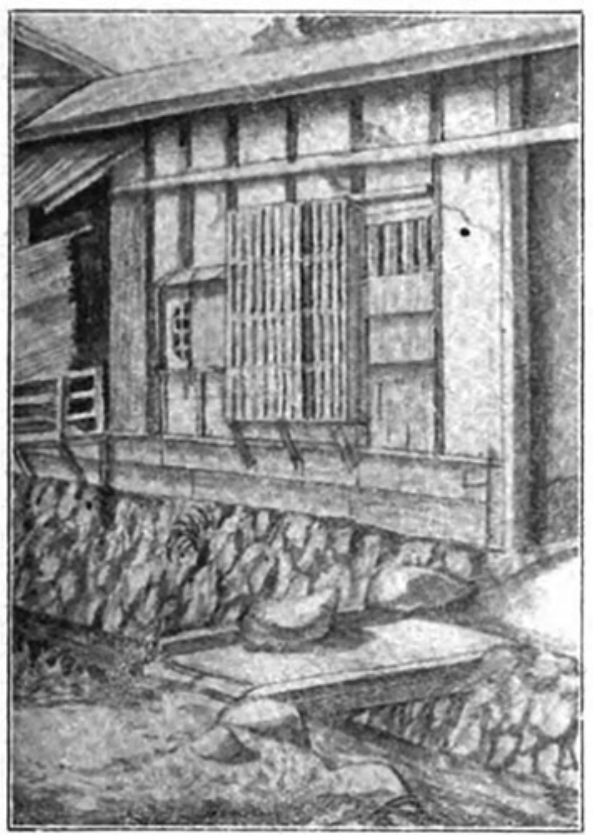

例：十五第及例一十五第

(躆二十三第) 四附

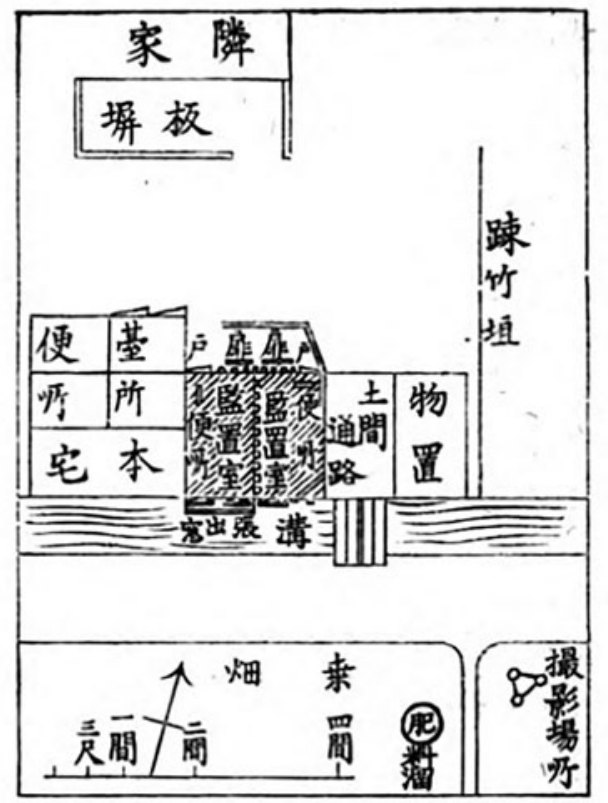

Figure 6. Examples 51 and 52, Floor Plan 32, Photograph 31 in Kure and Kashida (1918b).

confinement room. These spaces formed a concentric circle, with the confinement room occupying the center. The three spaces were linked by their physical arrangement as well as through concrete, everyday experiences of families and neighbors, including the labor of care, the movement across spatial boundaries, and sensory contact. Family members went in and out of confinement rooms to feed, bathe, and spend time with their confined member. In one instance, the wife and children of a confined man tended to his care, washing him every morning, cleaning his room, taking him on walks every few days, bathing him twice a week, and keeping his clothes clean (Kure and Kashida [1918] 2000 , 8). By consulting the floor plan for this man's house while looking at the photograph of his wooden cage, the viewer learns that it is indeed a door on the side of the cage, propped open in the photograph. It swung open and shut many times throughout the day.

The caretakers who moved in and out of confinement rooms were largely female, even though many legal custodians were fathers, husbands, and sons. The father of a mentally unstable man in Nagano, confined for hitting family members, served as the legal custodian, but the observing medical student pointed out that most of his care was performed by his brother's wife, who left his soiled clothing and quilt out to dry during the day and returned it to the room at night clean (Kure and Kashida [1918] 2000, 67). In another case in Nagano, an ex-soldier in confinement suffering from "unclean behavior" was tended by his elderly mother, who did not have the strength to do more than give him three meals a day. Twice a month she hired a laborer to bathe 


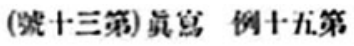

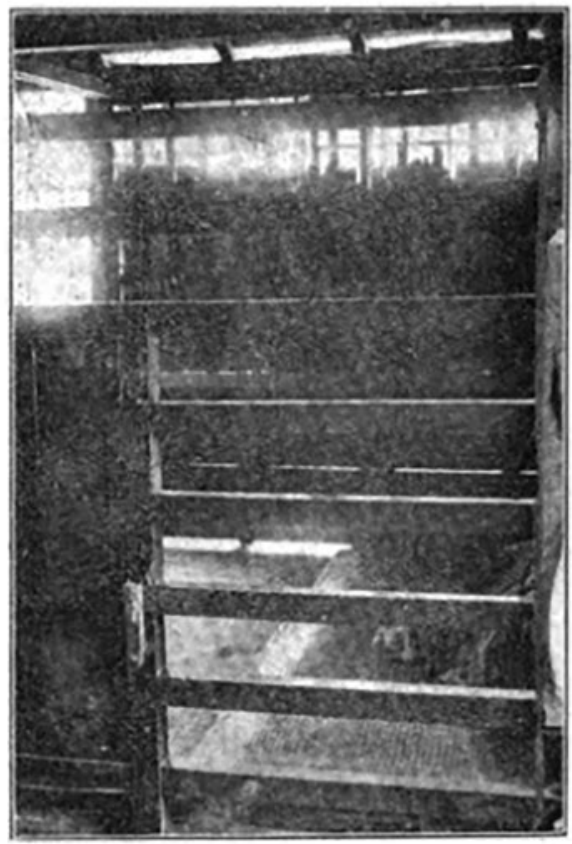

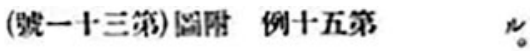
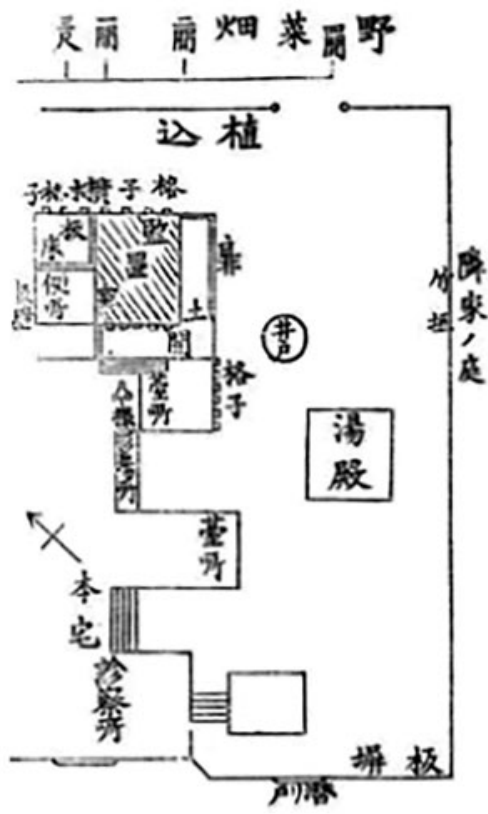

负

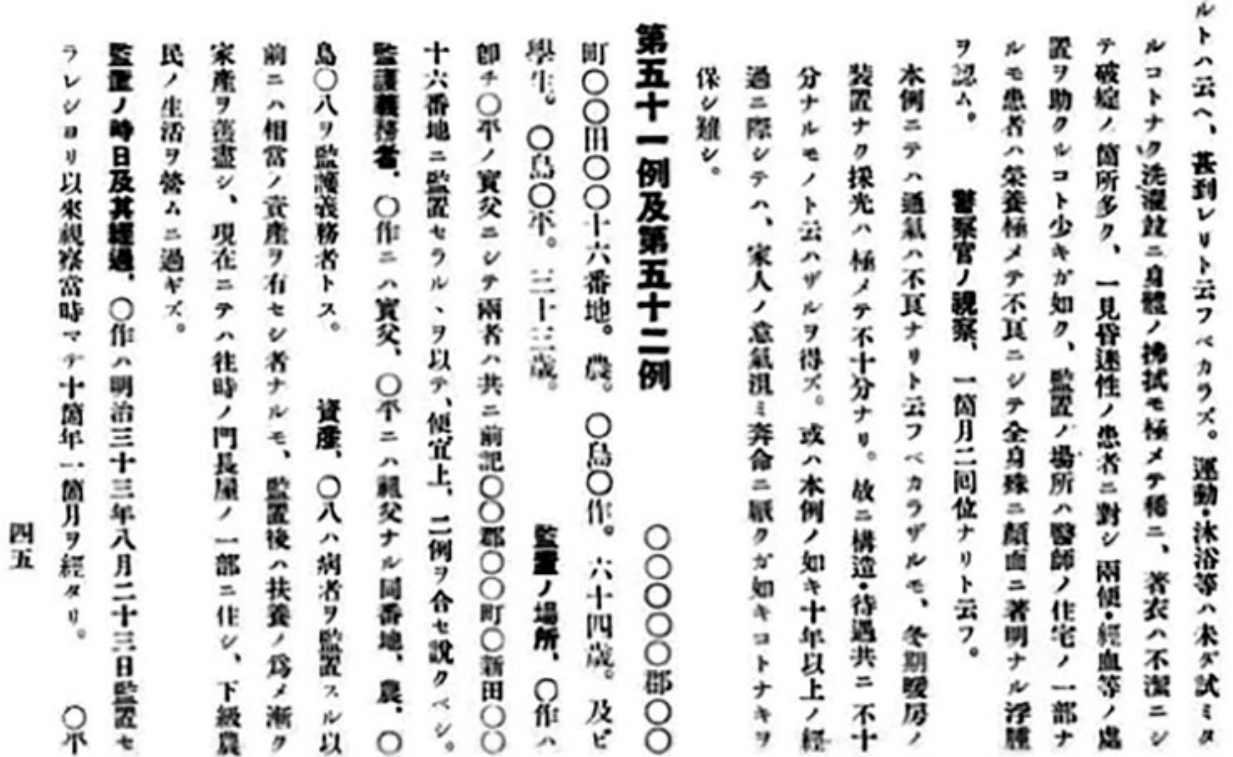

Figure 7. Example 50, Floor Plan 31, Photograph 3 in Kure and Kashida (1918b).

him and clean the room (66). And a woman confined for wandering the streets of Nagano after her divorce was in the custody of her brother-in-law, although her younger sister provided most of her care, cleaning the room three times a month (69-70). As was the 
case for most forms of domestic caregiving, whether for the mentally or physically ill, the women of the family bore most of the burden.

The juxtaposition of photographs, drawings, floor plans, and text alerted viewers to the sights, sounds, and smells that crossed the wooden bars and iron locks of cages. Such sensory contact enmeshed spaces of confinement with those of domesticity. Many of the observing medical students and psychiatrists bemoaned the unhygienic conditions of confinement rooms, noting the lack of ventilation that intensified the stench of waste matter and, in the case of women, clothing and bedding stained with menstrual blood. In extreme cases, the rooms and clothing of those who fell into dementia $(c h i h \bar{o})$ were also smeared with excrement or they were found playing with their own waste. Toilets were often not much more than holes in the ground, contributing to the odor emanating from the confinement area. The sounds of the sick reached the ears of family members and sometimes neighbors. Some yelled when agitated, while others sang songs.

Floor plans that graphically alert viewers to storage rooms and fields near the houses hint at how the demands of farming impinged upon the lives of the confined, linking together the labor of farm work and the labor of care. Most families needed all ablebodied members to help with the farm work and could not afford to lose a laboring hand to the supervision of the sick. Tending to the confined person was labor-intensive. Few families fed and bathed their sick member regularly. In order to bathe the person, families used a bathtub in the house, prepared a separate tub, or visited a public bath. Baths required the assistance of several family members, relatives, and neighbors, some even calling on the police for help. The arms and legs of agitated and quiet patients alike were tied during baths for fear of resistance that might endanger either the sick person or the caretaker. In many cases, families stopped bathing them altogether because of the difficulties involved (Kure and Kashida [1918] 2000, 10). Still, it was necessary to wash and clean their clothing, bedding, and rooms. Many cases in Kure's report told of families who hardly ever cleaned the cages because it was laborious and timeconsuming. Items would be dirtied again within a day or two, especially since many of the confined ripped their clothing and soiled the bedding. Many did not clean the confinement rooms or bathrooms (or even the person) more than once a month, others for as long as years at a time. Most families could not afford to spend time away from farm work to perform the labor of caregiving.

Kure and other psychiatrists questioned the primacy of the family in the management of the mentally disturbed by targeting the relationship between the socioeconomic status of households and the quality of caregiving. In their surveys, the medical students and psychiatrists explained that poorer families were compelled to work every day and therefore were unable to give sick members due attention. One woman in Nagano prefecture, whose husband was a peddler of raw silk and cocoons, was confined after she assaulted family members. Her mother and her children took care of her, but as psychiatrist Ujiie Makoto wrote, "the patient's family did not have much flexibility in their lifestyle and so the caretaking was insufficient, as they must devote all their time to silk work" (Kure and Kashida [1918] 2000, 25). The family of a thirty-six-year-old man from Fukushima prefecture observed by Kurosawa Yoshitami in 1912 did not have the means "to take care of the patient sufficiently because of the demands of labor on the farm" (52-53). In his report, Kure bemoaned the extreme neglect of the confined. "It is not possible," he 
wrote, "to suppress our sympathy for the [misfortune]" in such dire conditions. "However, we do not think families give this kind of thoughtless and cruel treatment intentionally. It is not that [persons interacting with the patient] have no sympathy or compassion. They are, after all, relations of parents and children, siblings, and couples" (129). In Kure's view, families neglected the confined not out of cruelty, but because the demands of farm work prevented them from providing proper care. He added that many of the already poor families were reduced to extreme poverty when forced to look after the sick.

Kure did not blame the families for the miseries of home confinement. He was convinced that families were ill equipped as caretakers. They did not, he said, have the experience of taking care of patients with dementia who engaged in such "unclean behavior" (fuketsu kōi) as playing with their excrement. "We must think about how, in the face of such illnesses, families that have no experience in giving care have no idea what to do. [Overwhelmed] with hardship and worry, in the end such [dire] conditions result" (Kure and Kashida [1918] 2000, 128). Although Kure believed that families' lack of material and emotional resources prevented them from administering proper care, the report also suggested that families neglected the mentally disturbed, seeing less of their humanity, as a result of increasing indifference, exhaustion, and humiliation at the seeming hopelessness of their condition.

\section{Conclusion}

The psychiatric campaign against home confinement helped pass in 1919 the Mental Hospitals Act (Seishinbyoin Hō), which called for the expansion of hospital-based public provisions. The Act empowered the Minister of Home Affairs to order prefectures to build public asylums in which poor patients could be admitted, promising that the central government would pay half of the cost for building the hospital and one-sixth of the cost for maintaining impoverished patients. Yet the passage of the Mental Hospitals Act did not create the nationwide system of hospital-based care that Kure and his fellow psychiatrists desired. Nor did it eliminate home confinement. ${ }^{14}$ Instead, it helped create two distinct forms of caregiving in urban and rural areas, with home confinement prevalent in the latter (Suzuki 2012). Unlike in cities where hospital facilities began to proliferate in the early twentieth century, there was a strong disincentive for public authorities in the countryside to pay for the establishment of public hospitals when families continued to bear the cost of managing madness under the terms of the Custody Law of 1900. By 1935, only twenty-two out of forty-seven prefectures had beds in psychiatric hospitals reserved for the public, most of which were located in private hospitals rather than public asylums, of which there were only a handful. Cities like Tokyo and Osaka placed approximately half of all registered mentally ill individuals in hospitals, but in many rural areas, the rates of hospitalized patients stayed below 1 percent, leading one historian to

\footnotetext{
${ }^{14}$ In the 1930s, some psychiatrists and social reformers expressed support for the custom of home confinement, calling it a uniquely Japanese form of extra-hospital, family-based care that surpassed systems of care in Western countries (Aoki 1937).
} 
conclude that "[t]he Mental Hospitals Act achieved virtually nothing in rural areas," where home confinement remained the norm (Suzuki 2012, 149). The practice would not be outlawed until 1950 with the passage of the Mental Hygiene Law by the Ministry of Health and Welfare.

Yet the significance of Kure's report can be assessed on terms beyond whether it achieved its intended effects. The report helped perpetuate the documentary mode, a crucial part of the process by which Western-derived science and medicine acquired persuasive power in Japan at the turn of the twentieth century. Kure's report reveals the workings of a representational strategy that made certain claims seem more truthful than others: those considered mentally ill deserved sympathy and medical care rather than stigmatization and neglect. The psychiatric point of view aimed to dominate those of legal scholars, government officials, and families by appealing to the sympathies of readers in a way that made such feelings seem natural and inevitable. Scholars have long recognized the role of documentation in the making of nation-states, empires, and populations; Kure's report sheds light on the formal and affective strategies behind such documentation.

Kure's report initiated the building of a visual archive of "the mentally ill" in modern Japan, which continued with such publications as The History of Tokyo's Public Matsuzawa Hospital and Statistics of Its Patients (1928) — an account of the first public mental asylum in Tokyo - and such cinematic visualizations of madness as director Teinosuke Kinugasa's silent film, Kurutta Ippēji (A Page of Madness, 1926). As in the case of hysteria in France, new visual technologies such as photography did not merely reflect, but helped constitute new disease categories and new ways of seeing those labeled mentally unsound as well as spaces of internment, whether the asylum or wooden cage (DidiHuberman 2003; Gilman 1976).

Kure and his fellow psychiatrists offered a vision of "the mentally ill" that was radical for their time. Their professional interest in expanding psychiatric institutions notwithstanding, they represented the humanity of both the confined and their families on terms that differed from those of policemen, legal scholars, and other officials. No other ethnographic or medical report of the time and beyond attempted to show the plight of families, many of whom were metaphorically caged in along with their mentally unsound members because of a lack of alternative sources of treatment. For the psychiatrists, treating those considered mentally ill as medical patients, that is, curable and treatable individuals, was tantamount to recognizing their humanity. Although the treatment of madness inside Japanese psychiatric hospitals throughout the twentieth century has arguably made some families and patients suffer in ways similar to experiences in home confinement, the initial psychiatric campaign to transform the confined into patients was driven in part by the hope that the afflicted, even in their marginalization and stigmatization, might be seen as fellow human beings.

\section{Acknowledgments}

I am grateful to Rebecca Brown, Tobie Meyer-Fong, Akihito Suzuki, Alan Tansman, and the two anonymous reviewers for their keen insights and feedback. 


\section{List of References}

Ambaras, David. 2005. Bad Youth: Juvenile Delinquency and the Politics of Everyday Life in Modern Japan. Berkeley: University of California Press.

Aoki, Masaharu. 1937. "Shitaku Kanchi no Jitsujyō ni Tsuite” [On the Real Conditions of Home Confinement]. Seishin Shinkeigaku Zasshi 41(11):1085-96.

Barclay, Paul D. 2016. "Playing the Race Card in Japanese-Governed Taiwan: Or, Anthropometric Photographs as 'Shape-Shifting Jokers." In The Affect of Difference: Representations of Race in East Asian Empire, eds. Christopher P. Hanscom and Dennis Washburn, 38-80. Honolulu: University of Hawai'i Press.

Blaxell, Vivian. 2009. “Designs of Power: The 'Japanization' of Urban and Rural Space in Colonial Hokkaidō." Asia-Pacific Journal: Japan Focus 7(35, no. 2). http://apjjf. org/-VivianBlaxell/3211/article.html (accessed January 20, 2017).

Burns, Susan. 2000. "Constructing the National Body: Public Health and the Nation in Meiji Japan.” In Nation Work: Asian Elites and National Identities, eds. Timothy Brook and Andre Schmid, 17-50. Ann Arbor: University of Michigan Press.

—. 2012. "Relocating Psychiatric Knowledge: Meiji Psychiatrists, Local Culture(s), and the Problem of Fox Possession." Historia Scientiarum 22(2):88-109.

— 2017. "Reinvented Places: 'Tradition,' 'Family Care' and Psychiatric Institutions in Japan." Social History of Medicine. doi:10.1093/shm/hkx066.

Didi-Huberman, Georges. 2003. Invention of Hysteria: Charcot and the Photographic Iconography of the Salpêtrière. Cambridge, Mass.: MIT Press.

Edwards, Elizabeth. 1992. Anthropology and Photography, 1860-1920. New Haven, Conn.: Yale University Press.

Garon, Sheldon. 1998. Molding Japanese Minds: The State in Everyday Life. Princeton, N.J.: Princeton University Press.

_ 2010. "State and Family in Modern Japan: A Historical Perspective." Economy and Society 39(3):317-36.

Gilman, Sander. 1976. The Face of Madness: Hugh W. Diamond and the Origin of Psychiatric Photography. New York: Brunner/Mazel.

Harding, Christopher, Iwata Fumiaki, and Yoshinaga Shin'ichi, eds. 2015. Religion and Psychotherapy in Modern Japan. London: Routledge.

Hashimoto, Акira. 2010. Chiryō no Basho to Seishin Iryōshi [Places of Healing and the History of Psychotherapy]. Tokyo: Nihonhyōronsha.

—. 2011. Seishinbyōsha to Shitaku Kanchi [Mental Patients and Home Confinement]. Tokyo: Rikka Shuppan.

Hiruta, Genshirō. 1985. Hayariyamai to Kitsunetsuki: Kinsei Shomin no Iryō Jijō [Epidemic Disease and Fox Possession: The State of Medical Treatments among EarlyModern Commoners]. Tokyo: Misuzu Shobō.

Нүṑō, Акıко. 2008. Seishinbyō no Nihon Kindai: Tsuku Shinshin Kara Yamu Shinshin E [Mental Illness in Japanese Modernity: From the Possessed Mind-Body to the Diseased Mind-Body]. Tokyo: Seikyūsha.

Itahara, Kazuko and Kuwabara Haruo. 1998. "Edo Jidai Koki ni Okeru Seishin Shōgai no Shogu (1)" [The Treatment of Mental Disability in the Late-Edo Period (1)]. Shakai Mondai Kenkyū 48(1):41-59.

1999. "Edo Jidai Koki ni Okeru Seishin Shōgai no Shogu (2)" [The Treatment of Mental Disability in the Late-Edo Period (2)]. Shakai Mondai Kenkyū 49(1): 93-111. 
2000a. "Edo Jidai Koki ni Okeru Seishin Shōgai no Shogu (3)" [The Treatment of Mental Disability in the Late-Edo Period (3)]. Shakai Mondai Kenkyū 49(2):183200.

2000b. "Edo Jidai Koki ni Okeru Seishin Shōgai no Shogu (4)" [The Treatment of Mental Disability in the Late-Edo Period (4)]. Shakai Mondai Kenkyū 50(1):79-94. 2001. "Edo Jidai Koki ni Okeru Seishin Shōgai no Shogu (5): Tōji no Ishi no Seiritsu Jyōkyō, Yakuwari, Sono Seishin Shōgai no Chishiki ni Tsuite" [The Treatment of Mental Disability in the Late-Edo Period (5): On the Formation, Circumstances, Functions, and Knowledge of Mental Disability among Physicians of the Time]. Shakai Mondai Kenkyū 50(2):1-45.

Kanekawa, Hideo. 2009. Seishinbyōin no Shakaishi [Social History of Mental Hospitals]. Tokyo: Seikyūsha.

. 2012. Nihon no Seishiniryō Shi: Meiji Kara Showa Shoki Made [History of Medical Treatments for the Mind in Japan: From the Meiji Period to the Early Showa Period]. Tokyo: Seikyūsha.

Katsu, Koкichi. [1843] 1969. Musui Dokugen: Hoka [Autobiography of Katsu Kokichi, or Musui Speaks to Himself]. Tokyo: Heibonsha.

KaWAI, TAKaO, ed. 1989-94. Kindai Nihon Shakai Chōsashi [History of Social Research in Modern Japan]. Vols. 1-3. Tokyo: Keiō Tsūshin.

Kazamatsuri, Hajıme. 2012. Kindai Seishinigakushi Kenkyū: Tōkyō Daigaku Gasshū Koku Gaichi no Seishinigaku [A Study of the History of Modern Psychiatry: The History of Psychiatry in the University of Tokyo, the United States, and the Colonies]. Tokyo: Chūō Kōron Jigyō Shuppan.

Keishi Ruiju Kisoku [Police Collection of Regulations]. 1879. Tokyo: Keishikyoku.

Kim, Gyewon. 2015. "Reframing 'Hokkaido Photography': Style, Politics, and Documentary Photography in 1960s Japan." History of Photography 39(4):348-65.

- 2016. "Faces that Change: Physiognomy, Portraiture, and Photography in Colonial Korea." In The Affect of Difference: Representations of Race in East Asian Empire, eds. Christopher P. Hanscom and Dennis Washburn, 133-58. Honolulu: University of Hawai'i Press.

Kinoshita, NaOyuki. 2003. “The Early Years of Japanese Photography." In The History of Japanese Photography, eds. Anne Wilkes Tucker et al., 14-99. New Haven, Conn.: Yale University Press in association with the Museum of Fine Arts, Houston.

Kure, Shūzō and Kashida Gorō. 1918a. "Seishinbyōsha Shitaku Kanchi no Jikkyō Oyobi Sono Tōkeiteki Kansatsu" [Actual Conditions of Home Confinement and Statistical Observations of the Mentally Ill]. Tōkyō Igakukai Zasshi 32(10-13):521-715.

—_. 1918b. Seishinbyōsha Shitaku Kanchi no Jikkyō Oyobi Sono Tōkeiteki Kansatsu [Actual Conditions of Home Confinement and Statistical Observations of the Mentally Ill]. Tokyo: Naimushō Eiseikyoku.

. [1918] 2000. Seishin Byōsha Shitaku Kanchi no Jitsujyō Oyobi Sono Tōkeiteki Kansatsu [Actual Conditions of Home Confinement and Statistical Observations of the Mentally Ill]. Tokyo: Sōzō Shuppan.

Low, Morris. 2003. “The Japanese Colonial Eye: Science, Exploration, and Empire.” In Photography's Other Histories, eds. Christopher Pinney and Nicolas Peterson, 100118. Durham, N.C.: Duke University Press.

Lydon, Jane. 2005. Eye Contact: Photographing Indigenous Australians. Durham, N.C.: Duke University Press. 
Ma, Zhiring. 2015. "An Iron Cage of Civilization? Missionary Psychiatry, the Chinese Family and a Colonial Dialectic of Enlightenment." In Psychiatry and Chinese History, ed. Howard Chiang, 91-110. London: Routledge.

Miller, IAn. 2013. The Nature of the Beasts: Empire and Exhibition at the Tokyo Imperial Zoo. Berkeley: University of California Press.

Minas, Harry, and Hervita Diatri. 2016. "Pasung: Physical Restraint and Confinement of the Mentally Ill in the Community." International Journal of Mental Health Systems 2(8). doi:10.1186/1752-4458-2-8.

Moran, James. 2007. "Architectures of Madness: Informal and Formal Spaces of Treatment and Care in Nineteenth-Century New Jersey." In Madness, Architecture, and the Built Environment: Psychiatric Spaces in Historical Context, eds. Leslie Topp, James E. Moran, and Jonathan Andrews, 153-72. New York: Routledge.

Nakamura, Masaichi. 2010. "Ugetsu Monogatari Kibitsu no Kama Kō: Shōtarō to Zashikirō" [The Parlor Prison of Shōtarō in "The Cauldron of Kibitsu" from Tales of Moonlight and Rain]. Shōkei Gakuin Kenkyū Kiyō 4:17-28.

Nakamura, Ōsamu. 2013. Rakuhōku Iwakura to Seishin Iryō: Seishinbyō Kanja Kazokuteki Kango no Dentō no Keisei to Shōshitsu [Rakuhōku Iwakura and Psychotherapy: The Formation and Disappearance of the Tradition of Familial Care for Mentally Ill Patients]. Kyoto: Seikaishisōsha.

Nornes, Markus. 2003. Japanese Documentary Film: The Meiji Era through Hiroshima. Minneapolis: University of Minnesota Press.

Окара, Hajime, ed. 1976-78. Haifū Yanagidaru Zensh $\bar{u}$ [The Complete Works of Haifū Yanagidaru]. 13 vols. Tokyo: Sanshōdō.

ОкаDа, YASUO. 1981. Shisetsu Matsuzawa Byōinshi: 1879-1980 [A History of Matsuzawa Hospital: 1879-1980]. Tokyo: Iwasaki Gakujutsu Shuppansha.

Oмata, WA’'ichirō. 2000. Seishinbyōin no Kigen: Kindai Hen [Origins of the Mental Hospital in the Modern Era]. Tokyo: Ōta Shuppan.

Ryan, James. 1997. Picturing Empire: Photography and the Visualization of the British Empire. Chicago: University of Chicago Press.

Ryan, Simon. 1996. The Cartographic Eye: How Explorers Saw Australia. Cambridge: Cambridge University Press.

Saitō, TAмаo. [1910] 2010-11. “Gunma-Ken Kanka Seishinbyōsha Shitaku Kanchi Jyōkyō Shisatsu Hōkoku” [Inspection Report on the Conditions of Private Confinement for the Mentally Ill under the Jurisdiction of Gunma Prefecture]. In Seishin Shōgaisha Mondai Shiryō Shūse [Collection of Historical Documents on Issues of the Mentally Disabled], eds. Okada Yasuo, Hashimoto Akira, and Komine Kazushige, 4:43-65. Tokyo: Rikka Shuppan.

. [1911] 2010-11. "Yamanashi Kenka Seishinbyōsha Shitaku Kanchi Jyōkyō Shisatsu Hōkoku" [Inspection Report on the Conditions of Private Confinement for the Mentally Ill in Yamanashi Prefecture]. In Seishin Shōgaisha Mondai Shiryō Shūse, eds. Okada Yasuo, Hashimoto Akira, and Komine Kazushige, 4:66-90. Tokyo: Rikka Shuppan.

Satō, Masahiro. 2013. Seishin Shikkan Gensetsu no Rekishi Shakaigaku: "Kokoro no Yamai" wa Naze Ryūkōsuru no Ka [A Historical Sociology of Discourses on Mental Disease: Trends in "Ailments of the Heart"]. Tokyo: Shinyōsha.

Shimazaki, Tōson. [1929] 1987. Before the Dawn. Translated by William E. Naff. Honolulu: University of Hawai'i Press.

Shorter, Edward. 1997. A History of Psychiatry: From the Era of the Asylum to the Age of Prozac. New York: John Wiley \& Sons. 
Silverberg, Miriam. 2006. Erotic Grotesque Nonsense: The Mass Culture of Japanese Modern Times. Berkeley: University of California Press.

Simonis, Fabien. 2010. "Mad Acts, Mad Speech, and Mad People in Late Imperial Chinese Law and Medicine." PhD diss., Princeton University.

Snyder, Joel. 2002. "Territorial Photography." In Landscape and Power, ed. W. J. T. Mitchell, 175-201. Chicago: University of Chicago Press.

Suzuki, Aкinito. 2003. "The State, Family, and the Insane in Japan, 1900-45." In The Confinement of the Insane: International Perspectives, 1800-1965, eds. Roy Porter and David Wright, 193-225. Cambridge: Cambridge University Press.

. 2012. "Between Two Psychiatric Regimes: Migration and Psychiatry in Early Twentieth-Century Japan." In Migration, Ethnicity, and Mental Health: International Perspectives, 1840-2010, eds. Angela McCarthy and Catharine Coleborne, 141-56. London: Routledge.

UjIIE, Макото. 1942. "Seishinbyō Sokumenshi 17" [A Side History of Mental Illness]. Seishin to Kagaku 6(8):13-18.

Umemori, Naoyuki. 2002. "Modernization through Colonial Mediations: The Establishment of the Police and Prison System in Meiji Japan.” PhD diss., University of Chicago.

Utsunomiya, Minori. 2009. "Seishinbyōsha Kango Hōan Teishutsu ni Itaru Yōin ni kansuru Kenkyū" [Research on the Reasons for Presenting a Bill on the Custodianship of the Mentally Ill]. Shakai Jigyōshi Kenkyū 36:109-22.

—. 2010. "Seishinbyōsha Kango Hō no 'Kango' Gainen no Kenshō” [A Verification of the Concept of "Custody" in the Custody Law for the Mentally Ill]. Shakai Fukushigaku 51(3):64-77.

Watarai, Yoshi'Ichi. 2003. Meiji no Seishin Isetsu: Shinkeibyō, Shinkei Suijaku, Kamigakari [Various Views on the Spirit in Meiji: Nervous Disease, Neurasthenia, and Spirit Possession]. Tokyo: Iwanami Shoten.

Wong, KA F. 2009. "Visual Methods in Early Japanese Anthropology: Torii Ryūzō in Taiwan." In Photography, Anthropology and History: Expanding the Frame, eds. Christopher Morton and Elizabeth Edwards, 171-91. Farnham, Surrey, UK: Ashgate.

Yamazaki, Tasuku. 1932. "Seishinbyōsha Shogun Kō 4" [Thoughts on the Treatment of Mental Patients 4]. Shinkeigaku Zasshi 34:399-412.

Yoo, Theodore Jun. 2016. It's Madness: The Politics of Mental Health in Colonial Korea. Oakland: University of California Press. 